\title{
MOBILE BANKING: ANALISA PENGGUNAAN PADA NASABAH \\ PT. BANK ACEH SYARIAH CABANG LHOKSEUMAWE: PENDEKATAN TECHNOLOGY ACCEPTANCE MODEL (TAM)
}

\author{
Rahmawati ${ }^{1}$, Dhalilah Shuba Haq ${ }^{2}$
}

\begin{abstract}
Astrak
Mobile banking menawarkan kemudahan dalam melakukan transaksi perbankan Bagi nasabah yang menggunakan mobile banking akan mendapatkan informasi nasabah dalam melakukan transaksi perbankan. PT Bank Aceh Syariah Cabang Lhokseumawe Cabang Lhokseumawe, sebagai salah satu institusi perbankan sangat menyadari bahwa pelayanan kepada nasabah harus disesuaikan dengan kemajuan pandangan teknologi. Penelitian ini membatasi hanya menggunakan tiga faktor dan perlu diperhatikan oleh peneliti, dikarenakan Technology Acceptance Model (TAM) sebagai model penerimaan pengguna pada suatu sistem informasi..Berdasarkan analisis tersebut diketahui bahwa atau konstanta sebesar 92,343\% artinya ketiga variabel yaitu Persepsi Kemudahan, Kenyamanan, dan Kepercayaan mempunyai pengaruh terhadap variabel preferensi sebesar 21,453\%, koefisien regresi variabel persepsi kemudahan (X1) sebesar $55,7 \%$, koefisien regresi variabel kenyamanan (X2) sebesar 27,9\%, dan koefisien regresi variabel kepercayaan (X3) sebesar 93,8\%. Berdasarkan hasil Uji $F$ dan Uji $t$ dapat dilihat bahwa faktor yang paling dominan mempengaruhi minat nasabah menggunkan mobile banking adalah faktor kepercayaan karena nilai variabel kepercayaan lebih besar mempengaruhi dari variabel lain.
\end{abstract}

Kata Kunci: Mobile Banking, TAM,

1, 2 Dosen IAIN Lhokseumawe Email:zidnirahma@gmail.com 


\section{PENDAHULUAN}

Pada era globalisasi ini Indonesia telah mengalami perkembangan ekonomi dan teknologi yang pesat. Teknologi informasi sudah merupakan suatu kebutuhan yang sangat penting, bahkan sebagai tuntutan yang mendesak bagi setiap orang untuk menyelesaikan semua permasalahan dengan cepat serta meringankan semua pekerjaannya. Seiring dengan situasi seperti ini, perkembangan teknologi informasi terutama peranan komputer mendapatkan perhatian yang sangat serius. Teknologi informasi ini memberi dampak luar biasa dalam dunia perbankan saat ini. Akhir-akhir ini banyak sekali perubahan pada teknologi informasi, demikian juga di bidang telekomunikasi, perkembangan teknologi semakin hari semakin pesat, akan tetapi apakah kita siap atau tidak dalam mengikuti perkembangan teknologi tersebut.

Perkembangan teknologi informasi menciptakan jenis dan peluang bisnis yang baru dimana transkasi-transaksi bisnis makin banyak dilakukan secara elektronika. Berkaitan dengan perkembangan teknologi informasi tersebut memungkinkan setiap orang dengan mudah melakukan transaksi perbankan. Perkembangan mobile banking memang cepat dan memberi pengaruh signifikan dalam aspek kehidupan kita. Penggunaan teknologi tidak hanya terbatas pada pemanfaatan informasi yang dapat diakses melalui media, namun handphone, tablet, juga dapat digunakan sebagai sarana untuk melakukan transaksi perbankan. Selama beberapa tahun terakhir ini, bank komersial telah memperkenalkan sistem perbankan berbasis aplikasi untuk meningkatkan operasional dan mengurangi biaya. Mobile banking merupakan salah satu bentuk produk jasa yang mulai banyak ditawarkan oleh bank-bank komersial di Indonesia. Oleh karena alasan kemudahan dan kegunaannya, mulai banyak nasabah bank di Indonesia yang menggunakan fasilitas mobile banking dalam transaksi perbankan. Transaksi perbankan dapat dilakukan kapan dan dimana saja tanpa dibatasi tempat dan waktu, dengan adanya mobile banking nasabah suatu bank akan semakin mudah untuk melakukan kegiatan perbankan, karena para nasabah dapat mengakses layanan yang diinginkan oleh nasabah tanpa harus datang ke bank yang bersangkutan.

Mobile banking menawarkan kemudahan dalam melakukan transaksi perbankan. Keuntungan dari menyediakan layanan mobile banking bagi bank adalah menghemat biaya percetakan formulir yang harus diisi oleh nasabah untuk bertransaksi, brosur, katalog, dan menggantinya dengan data elektronik. Bagi nasabah yang menggunakan mobile banking akan mendapatkan informasi nasabah dalam melakukan transaksi perbankan.

Banyaknya nasabah yang ingin melakukan transaksi dengan cepat dan menghemat waktu menjadikan nasabah minat terhadap penggunaan mobile banking. Mobile banking dilandasi oleh berbagai faktor antara lain: persepsi kemudahan, kenyamanan, kredibilitas, manfaat, daya guna, resiko, kualitas layanan dan kepercayaan. 
Maka dalam penelitian ini, faktor tersebutkan menjadi variabel penelitian. Namun penelitian ini membatasi hanya menggunakan tiga faktor dan perlu diperhatikan oleh peneliti, dikarenakan Technology Acceptance Model (TAM) sebagai model penerimaan pengguna pada suatu sistem informasi. Sesuai dengan TAM, penggunaan sistem (actual system usage) paling dipengaruhi oleh minat untuk menggunakan (behavioral intentions toward usage). Behavioral intentions toward usage dipengaruhi oleh kepercayaan, yaitu persepsi pengguna terhadap kemudahan (perceived ease of use) dan menurut Poon kenyamanan dalam penelitian merupakan variabel utama.

PT Bank Aceh Syariah Cabang Lhokseumawe Cabang Lhokseumawe sebagai salah satu institusi perbankan syariah di Aceh sangat menyadari bahwa pelayanan kepada nasabah harus disesuaikan dengan kemajuan pandangan teknologi. Terobosan-terobosan baru harus dirancang agar dapat terus berkembang dan bersaing atau paling tidak bisa mempertahankan eksistensi, artinya dengan bersentuhan pada teknologi maka PT Bank Aceh Syariah Cabang Lhokseumawe akan tetap dapat bersaing sehingga PT Bank Aceh Syariah Cabang Lhokseumawe perlu penambahan jasa layanan mobile banking. Kita bisa melihat perkembangan yang terjadi dari tahun ke tahun mengalami peningkatan pada minat nasabah untuk menggunakan layanan mobile banking. Tingginya penggunaan mobile banking oleh nasabah Bank Aceh Syariah ini menarik untuk dilakukan suatu penelitian untuk menganalisis faktor-faktor apa saja yang mempengaruhi minat nasabah untuk menggunakan mobile banking. Hal ini penting karena hasil penelitian ini dapat memberikan petunjuk bagi industri perbankan, yaitu Bank Aceh Syariah untuk dapat merumuskan strategi pemasaran mereka, untuk menjaga konsistensi dan keunggulan kompetitif produk phone banking (mobile banking) di masa yang akan datang.

Berdasar latar belakang yang dikemukakan. Maka masalah pokok dalam penelitian ini yaitu:

1). Apakah Persepsi kemudahan, kenyamanan, dan kepercayaan berpengaruh signifikan terhadap minat nasabah untuk menggunakan mobile banking?

2). Faktor manakah yang paling dominan mempengaruhi minat nasabah untuk menggunakan mobile banking?

\section{METODE PENELITIAN}

\subsection{Minat}

Minat adalah salah satu aspek psikis yang dapat mendorong manusia mencapai tujuan. Seseorang yang memiliki minat terhadap suatu objek, cenderung memberikan perhatian atau merasa senang yang lebih besar kepada objek tersebut. Namun, apabila objek tersebut tidak menimbulkan rasa senang, maka orang itu tidak akan memiliki minat atas objek tersebut. Oleh karena itu, tinggi rendahnya perhatian atau rasa senang seseorang 
terhadap objek dipengaruhi oleh tinggi rendahnya minat seseorang tersebut.

Minat merupakan suatu dorongan yang kuat dalam diri seseorang terhadap sesuatu. Minat merupakan rasa lebih suka dan rasa ketertarikan pada suatu hal atau aktivitas, tanpa ada yang menyuruh keinginan seseorang akan sesuatu menimbulkan kegairahan terhadap sesuatu tersebut. Slament0 (2007)

Faktor-faktor yang mempengaruhi minat nasabah menggunakan mobile banking yaitu:

a. Persepsi Kemudahan adalah variabel utama dalam menggunakan teknologi informasi (mobile banking). Persepsi Kemudahan, merupakan salah satu faktor penting bagi pengguna untuk bertransaksi menggunakan internet banking dengan fleksibilitas waktu dan tempat, karena dapat dilakukan kapan dan dimana saja.

b. Kenyamanan merupakan hal yang penting bagi nasabah dalam menggunakan layanan transaksi mobile banking karena dapat memudahkan akses mobile banking menjadikan pengguna meraskan kenyamanan dalam bertransaksi.

c. Kepercayaan adalah keyakinan pada diri seseorang terhadap obyek. Kepercayaan yang dimaksud disini adalah kepercayaan nasabah pada penyelenggara transaksi elektronik perbankan, serta kepercayaan pada mekanisme operasional dari transaksi yang dilakukan. Kepercayaan, merupakan hal yang harus dipertimbangkan dalam mengambil keputusan apabila akan menggunakan layanan mobile banking.

\subsection{Persepsi Kemudahan}

Pengertian Persepsi Kemudahan, didefinisikan sebagai tingkat dimana seseorang meyakini bahwa penggunaan teknologi informasi merupakan hal yang mudah dan tidak memerlukan usaha keras dari pemakainya. Konsep ini mencakup kejelasan tujuan penggunaan IT dan kemudahaan penggunaan sistem untuk tujuan sesuai dengan keinginan pemakai. Dalam TAM, faktor persepsi terhadap kemudahan untuk menggunakan teknologi berhubungan dengan sikap seseorang pada penggunaan teknologi tersebut. Sikap pada penggunaan sesuatu adalah sikap suka atau tidak suka terhadap penggunaan suatu produk. Sikap suka atau tidak suka terhadap suatu produk ini dapat digunakan untuk memprediksi perilaku niat seseorang untuk menggunakan suatu produk atau tidak menggunakannya.

Davis memberikan beberapa indikator persepsi kemudahan dalam Teknologi informasi meliputi:

1. Sangat mudah dipelajari

2. Mengerjakan dengan mudah apa yang diinginkan oleh pengguna

3. Sangat mudah untuk dioperasikan. 


\subsection{Kenyamanan}

Mobile banking menyediakan tingkat kenyamanan yang lebih tinggi yang mana memudahkan nasabah untuk melakukan transaksi perbankan kapanpun dan di manapun. Jika dibandingkan dengan transaksi perbankan tanpa menggunakan mobile banking misalnya dengan transaksi interpersonal, mobile banking memberikan lebih banyak keuntungan dan kemudahan. Seperti misalnya, jika ingin membayar tagihan atau mentransfer uang, apabila melalui kantor cabang, maka nasabah harus mengantri lama untuk melakukan transaksi tersebut. Hal ini tentunya kurang memberikan kenyamanan bagi nasabah. Berbeda jika transaksi tersebut dilakukan dengan mobile banking. Jika menggunakan mobile banking, transaksi tersebut cukup dilakukan dengan mengakses aplikasi mobile banking pada smartphone kapanpun dan dimanapun nasabah berada. Tentunya hal ini akan lebih menghemat waktu nasabah, khususnya bagi nasabah yang sibuk.

Menurut Nisa,dkk (2013) Terdapat beberapa konstruk yang merupakan indikator kenyamanan suatu sistem mobile banking, yaitu sebagai berikut:

1). Nasabah dapat mengakses mobile banking kapanpun dan di manapun (anytime and anywhere).

2). Tidak terdapat antrian (queue).

3). Hemat waktu jika dibandingkan dengan cara konvensional (convensional banking) yang kemudian mereka akan berminat untuk menggunakannya di masa yang akan datang.

\subsection{Keperecayaan}

Untuk dapat mempertahankan hubungan jangka panjang dengan para nasabahnya, pihak bank perlu menganut konsep kepuasan pelanggan agar dapat bertahan hidup dalam era e-banking, pihak bank harus mempunyai pelanggan loyal yang percaya terhadap ekselensi jasa online. Seiring maraknya kejahatan internet seperti pembobolan akun faktor kepercayaan menjadi hal yang sangat penting penggunaan mobile banking dalam transaksi perbankan. Fadhil, dkk (2016)

Konsep kepercayaan ini berarti bahwa nasabah percaya terhadap keandalan pihak bank dapat menjamin keamanan dan kerahasiaan akun nasabah. Keamanan berarti penggunaan itu aman, resiko hilangnya data atau informasi sangat kecil, dan resiko pencurian rendah. Sedangkan kerahasiaan berarti bahwa segala hal yang berkaitan dengan informasi pribadi pengguna terjamin kerahasiaannya, tidak ada pihak ketiga yang dapat mengetahuinya. Dalam hal penggunaan mobile banking, kebanyakan pengguna tidak memahami betul risiko keamanan dan kerahasiaan dari mobile banking. Mereka hanya beranggapan bahwa pihak bank telah memperhatikan keamanan dan kerahasiaan, padahal pengguna tidak mengetahui seberapa kuatnya keamanan dan kerahasiaan dari mobile banking. Oleh karena itu, kepercayaan nasabah merupakan faktor penting yang mendorong nasabah un- 
tuk bertransaksi perbankan.

Kepercayaan muncul ketika adanya keyakinan dari pihak konsumen yaitu pelanggan pada reliabilitas dan integritas dari rekan pertukaran. Kepercayaan disini adalah kepercayaan nasabah pada penyelenggara transaksi elektronik perbankan, serta kepercayaan pada mekanisme operasional dari transaksi yang dilakukan. terdapat beberapa indikator dalam variabel kepercayaan yaitu:

a. Kehandalan

Kehandalan artinya kemampuan memberikan pelayanan yang dijanjikan kepada para nasabah dengan segera, akurat, dan memuaskan.

b. Kepedulian

Kepedulian merupakan sikap empati yang tinggi yang dapat dirasakan pihak bank mampu memberikan solusi atau menyelesaikan permasalahan yang dialami oleh nasabah.

c. Kredibilitas

Kredibilitas artinya penyelenggaraan mekanisme operasional transaksi elektronik perbankan yang jujur dan dapat dipercaya.

\subsection{Mobile Banking}

Aplikasi merupakan program software yang dapat didownload melalui smartphone ataupun tablet. Mobile Banking merupakan salah satu layanan berupa aplikasi. Mobile banking adalah layanan perbankan berbentuk aplikasi yang dapat diakses langsung melalui jaringan telepon seluler/handphone GSM (Global For Mobile Comunication) atau CDMA dengan menggunakan layanan data yang telah disediakan oleh operator seluler. Untuk mendapatkan fasilitas ini, nasabah harus mengisi surat permohonan kepada bank dan me-register nomor handphone yang akan digunakan di samping password untuk keamanan bertransaksi.

Penelitian ini hanya membahas tentang faktor-faktor yang mempengaruhi Minat Nasabah terhadap penggunaan internet banking dilandasi oleh berbagai faktor antara lain Persepsi Kemudahan Penggunaan, Persepsi Daya Guna, Kenyamanan dan Kepercayaan pada PT Bank Aceh Syariah.

Jenis penelitian merupakan teknik atau prosedur yang dilakukan dalam suatu penelitian. Jenis penelitian yang digunakan dalam penelitian ini adalah penelitian kuantitatif, karena penelitian ini bersifat deskriptif yaitu penelitian yang dimaksud, adalah untuk mengumpulkan informasi mengenai suatu gejala yang ada menurut apa adanya pada saat penelitian dilakukan yang terjadi pada masa sekarang. Arakunto (2005) 
Sumber data dalam penelitian ini terbagi dua yaitu:

1) Data primer

Dalam penelitian ini data primer merupakan data yang di peroleh dari penyebaran kuesioner terhadap responden serta melakukan wawancara dengan responden di Bank Aceh Syariah.

2) Data Sekunder

Dalam penelitian ini data sekunder merupakan data yang diperoleh dari instansi yang berkedudukan sebagai pemberi informasi tentang data khsusnya jumlah keseluruhan nasabah yang ada pada Bank Aceh Syariah di bagian Back Office (BO).

Populasi merupakan objek atau subjek yang berada pada suatu wilayah dan memenuhi syarat-syarat tertentu yang berkaitan dengan masalah penelitian. Ridwan (2007)

Sedangkan Sampel menunjukkan bagian dari populasi yang memiliki karakteristik yang sama dan mewakili populasi penelitian. Populasi dalam penelitian ini adalah jumlah nasabah yang menggunakan internet banking di bank Aceh Syariah Lhokseumawe. Mengingat Jumlah populasi yang relatif besar maka perlu dilakukan pengambil sampel. Teknik pengambilan sampel yang digunakan dalam penelitian ini adalah metode proportional random sampling yaitu teknik pengambilan sampel dengan memperhatikan proporsi jumlah sub-sub populasi.

Jumlah sampel dari total populasi ditentukan dengan rumus yang dikemukakan oleh Ridwan adalah sebagai berikut:

$$
\mathrm{n}=\frac{N}{N(d)^{2}+1}
$$

Keterangan:

$\mathrm{n}=$ Jumlah sampel yang dicari

$\mathrm{N}=$ Jumlah Populasi

$\mathrm{d}^{2}=$ Nilai presisi yang ditetapkan $(0,1)$.

\section{TEKNIK PENGUMPULAN DATA}

Berkaitan dengan bagaimana data dalam penelitian ini diperoleh. Metode atau cara pengumpulan data yang digunakan dalam penelitian ini adalah sebagai berikut:

\subsection{Kuisioner}

Kuisioner berupa sejumlah pertanyaan tertulis yang digunakan untuk memperoleh informasi dari responden. Dalam penelitian ini kuisoner di bagikan kepada nasabah BAS sebagai responden. Adapun alasan yang digunakan dalam metode kuisioner ini sebagai alat pengumpul data dalam penelitian adalah sebagai berikut: 
a). Interprestasi subyek terhadap pertanyaan yang diajukan kepada responden adalah sesuai dengan maksud peneliti.

b). Dalam menjawab pertanyaan responden dapat lebih leluasa, karena tidak dipengaruhi oleh sikap mental hubungan antar responden dengan peneliti.

c). Data yang terkumpul dapat dengan mudah dianalisa, masing-masing jawaban akan diberi skor nilai sesuai dengan pilihan jawaban.

d). Dalam penelitiaan ini menggunakan data primer yaitu metode kuisioner dengan menyebar kuisioner ke responden (nasabah) BAS.

Dalam peneliitian ini, teknik yang digunakan untuk pengumpulan data adalah secara pengukuran skala 5 tingkat (likert) yaitu merupakan penyebaran formulir-formulir yang berisi pertanyaan-pertanyaan yang diajukan secara tertulis kepada seseorang atau sekumpulan orang untuk mendapatkan jawaban atau tanggapan. Informasi yang penting bagi peneliti, seperti skala pengukuran kinerja, diukur dengan:

\begin{tabular}{ccc}
\hline No & Keterangan pilihan & Skor \\
\hline 1 & Sangat tidak setuju & 1 \\
2 & Tidak setuju & 2 \\
3 & Netral & 3 \\
4 & Setuju & 4 \\
5 & Sangat setuju & 5 \\
\hline
\end{tabular}

Wawancara adalah proses memperoleh keterangan data untuk tujuan penelitian dengan cara tanya jawab, sambil bertatap muka antara pewawancara dengan responden dengan menggunaka alat yang dinamakan panduan wawancara.Siregar (2013)

\subsection{Teknik Analisis Data}

Analisis data yang digunakan dalam pengujiuan hipotesis dilakukan secara kuantitatif melalui angket untuk menguji hipotesis dengan melakukan editing yang dimaksudkan untuk mempermudah pemilihan dan hasil penelitian. Penelitiaan akan memberikan kode pada hasil penelitian untuk mempermudah pengolahan data secara umum dan khusus. Untuk pengujian hipotesis penelitian, akan digunakan rumus Regresi linear berganda. Pengujian angket dapat penulis analisis melalui beberapa pengujian berikut ini:

\section{1). Uji Validitas}

Validitas adalah suatu ukuran yang menunjukkan tingkat-tingkat kevalidan atau kesahihan sesuatu instrumen. (Arakuntp (2006) Data dikataka valid, jika pertanyaan pada angket mampu mengungkapkan sesuatu yang diukur oleh angket tersebut.Untuk menguji kevalitan suatu data maka dilakukan uji validitas terhadap butir-butir angket. Ting- 
gi rendahnya validitas suatu angket atau angket dihitung dengan menggunakan metode pearson's product moment correlation, yaitu dengan menghitung korelasi antar item pertanyaan dengan skor total.

Kriteria pengujian validitas adalah dengan membandingkan $r_{\text {hitung }}$ dengan $r_{\text {tabel}}$, pada taraf signifikan 95\% atau 5\%. Menurut sugiono, item pertanyaan diebut valid jika butir pertanyaan memiliki $r_{\text {hitung }}>r$ standar $=0,30$. Dalam hal ini, yang dimaksud $r_{\text {hitung }}$ untuk setiap item pertanyaan, adalah koefisien korelasi product moment antara skor masing-masing item tersebut dengan total skor seluruh item yang dinotasikan dengan corrected item. Total correlation pada hasil perhitungan SPSS untuk setiap item pertanyaan dari sebuah variabel.

\section{2). Uji Reabilitas}

Reabilitas adalah tingkat kemampuan suatu instrumen penelitian untuk mengukur suatu variabel secara berulangkali dan mampu menghasilkan informasi atau data yang sama atau sedikit seai bervariasi. Teknik pengujuan reabilitas menggunakan konfensiensialpha crombach dengan taraf nyata 5\%. Jika konfensiensi lebih besar dari nilai kritis atau alpha crombach lebih besar dari pada 0,7 maka item tersebut dinyatakan reliabel. Konfensien alpha kurang dari 0,7 menunjukkan reabilitasnya buruk, angka sekitar 0,771 menunjukkan reabilitas data diterima dan angka di atas 0,8 menunjukkan reabilitas yang baik.

\section{Uji Asumsi Klasik}

Model regresi pengujian asumsi klasik yang digunakan dalam penelitian ini ada 3, yaitu uji normalitas, uji multikolinearitas, uji heteroskedatisitas, dan uji autokorelasi.

\section{a. Uji normalitas}

Uji normalitas bertujuan untuk menguji apakah model regresi, variabel pengganggu atau residual memiliki konstribusi normal. Untuk menguji normalitas data dapat digunakan uji statistik kolmogorov Swirnov (KS) yang dilakukan dengan membuat hipotesis nol (Ho) Untuk data berdistribusi normal dan hipotesis alternatif (Ha) untuk data berkontribusi non parametrik kolmogorov swirnov.

Hipotesis yang dikemukakan:

$\mathrm{Ho}=$ data residual berdistribusi normal (Asymp.sig $>0,05)$

$\mathrm{Ha}=$ data residual tidak berditribusi normal (Asymp.sig<0,05)

\section{c. Uji multikolinearitas}

Multikoinearitas adalah adanya suatu hubungan linear yang sempurna antara beberapa atau semua variabel independen. Uji multikolinearitas bertujuan untuk menguji apa- 
kah model regresi ditemukan adanya kolerasi antar variabel bebas (independen). Model regresi yang seharusnya tidak terjadi kolerasi diantara variabel independen. Jika variabel independen saling berkorelasi, maka variabel-variabel ini todak orthogonal. Variabel orthogonal adalah variabel independen yang nilai kolerasi antar sesama variabel independen sama dengan nol.

Multikolinearitas dideteksi dengan menggunkan nilai tolerance dan variance inflasion factor (VIF). Kedua ukuran ini menunjukkan setiap variabel independen manakah yang dielaskan oleh variabel independen lainnya. Tolerance mengukur variabilitas variabel independen yang terpilih, yang tidak dapat dijelaskan oleh variabel independen lainnya. Nilai tolerance rendah sama dengan nilai VIF tinggi (karena VIF=1/tolerance). Nilai cut-off yang umum dipakai untuk menunjukkan adanya multikolonieritas adalah nilai tolerance $\leq 0.01$ atau sama dengan $\mathrm{VIF} \geq 10$.

\section{d. Uji Heteroskedastisitas}

Uji heteroskedasisitas untuk menguji apakah dalam model regresi terjadi ketidaksamaan varian dari residual satu pengamatan ke pengamatan lain. Jika varian dan residual satu pengamatan ke pengamatan lain tetap, maka disebut homoskedastisitas dan jika berbeda disebut heteroskedastisitas. Model regresi yang baik adalah homoskedastisitas atau tidak terjadi heteroskedastisitas.

Salah satu cara untuk mendeteksi adanya heteroskedatisitas adalah dengan melihat grafik plot antara nilai prediksi variabel independen (ZPRED) dengan residualnya (SRESID). Deteksi ada tidaknya heteroskedastisitas dapat dilakukan dengan melihat ada tidaknya pola tertentu pada grafik scatterplot antara ZPRED dan SRESID dimana sumbu Y adalah Y yang telah diprediksi, dan sumbu X adalah residual (Y prediksi-Y sesungguhnya) yang telah di studentized.

\section{a. Uji Autokolerasi}

Tujuan pengujian ini adalah untuk mengatuhi apakah terdapat kolerasi atau tidak antara kesalahan pengganggu pada periode $t$ dengan periode sebelumnya (t-1). Jika terjadi kolerasi, maka dinamakan ada problem autokolerasi. Autokolerasi muncul karena observasi yang berurutan sepanjang waktu berkaitan satu sama lainnya. Masalah ini timbul karena residual (kesalahan pengganggu) tidak bebas dari satu observasi lainnya. Model regresi yang baik adalah regresi yang brbas dari auto kolerasi.

\section{Regresi Linear Berganda}

Penelitian ini menggunakan rumus regresi berganda. Kegunaan regrei berganda dalam penelitian ini adalah untuk meramalkan dan memprediksikan variabel terikat (dependen), apabila variabel bebas (independen) diketahui. Yang menjadi variabel terikat 
(dependen) dalam penelitian ini adalah minat nasabah disimbol dengan Y, dan yang menjadi variabel bebas (independen) adalah presepsi kemudahan penggunaan disimbolkan dengan $\mathrm{X}_{1}$, kenyamanan disimbolkan dengan $\mathrm{X}_{2}$, kepercayaan disimbolkan dengan $\mathrm{X}_{3}$.

\section{Uji Hipotesis}

\section{a. Uji f}

Adalah uji pengaruh secara bersama-sama variabel-variabel bebas terhadap variabel tidak bebas. Uji f pada penelitian ini menggunakan SPSS. Dengan derajat keyakinan 95 persen atau signifikasi $(\alpha) 5$ persen dan derajat kebebasan (df) sebesar (k-1) (m-1) maka hipotesisnya adalah:

Pengambilan keputusan:

$\mathrm{Ha}_{1}$ ditolak, apabila $\mathrm{F}_{\text {hitung }}<\mathrm{F}_{\text {tabel }}$ pada $\alpha=0,05$

$\mathrm{Ha}_{1}$ diterima, apabila $\mathrm{F}_{\text {hitung }}>\mathrm{F}_{\text {tabel }}$ pada $\alpha=0,05$

\section{a. Uji t}

Untuk memastikan masing-masing variabel bebas berpengaruh secara parsial terhadap variabel tidak bebas, penelitian ini menggunakan uji t. Uji t untuk menghitung analisa faktor-faktor yang memprngaruhi minat nasabah terhadap internet banking.

Dengan derajat keyakinan 95 persen atau signifikasi $(\alpha) 5$ persen dan derajat kebabasan (df) sebesar (N-k) maka menarik kesimpulan dengan criteria sebagai berikut:

$\mathrm{H}_{\mathrm{a} 1}$ ditolak, apabila $\mathrm{t}_{\text {hitung }}<\mathrm{t}_{\text {tabel }}$ pada $\alpha=0,05$

$\mathrm{H}_{\mathrm{a} 1}$ diterima, apabila $\mathrm{t}_{\text {hitung }}>\mathrm{t}_{\text {tabel }}$ pada $\alpha=0,05$

\section{Koefesien Determinasi $\left(\mathbf{R}^{2}\right)$}

Koefesiensi Determinasi $\left(\mathrm{R}^{2}\right)$ pada intinya mengukur seberapa jauh kemampuan model dan menerangkan variasi variabel dependen. Nilai koefesien adalah antara nol dan satu. Nilai $\mathrm{R}^{2}$ yang kecil berarti kemampuan variabel-variabel independen dalam menjelaskan variasi variabel dependen amat terbatas. Nilai yang mendekati satu berarti variabel-variabel independen memberikan hampir semua informasi yang dibutuhkan untuk memprediksikan variasi variabel dependen.

Dalam proses pengolahan data, penulis mempergunakan aplikasi komputer dengan SPSS untuk mempermudah dan mempercepat pengolahan data. SPSS adalah suatu software yang berfungsi untuk menganalisa data, melakukan perhitungan statistik baik untuk statistik parametik maupun non parametik dengan basis windows.

Dengan demikian, populasi penelitian adalah Jumlah nasabah yang ada pada PT Bank Aceh Syariah Cabang Lhokseumawe. Teknik pengambilan sampel yang digunakan 
dalam penelitian ini adalah metode proportional random sampling yaitu teknik pengambilan sampel dengan memperhatikan proporsi jumlah sub-sub populasi.

Jumlah sampel dari total populasi ditentukan dengan rumus sebagai berikut:

$$
\mathrm{n}=\frac{N}{N(d)^{2}+1}
$$

Keterangan:

$\mathrm{n}=$ Jumlah sampel yang dicari

$\mathrm{N}=$ Jumlah Populasi

$\mathrm{d}^{2}=$ Nilai presisi yang ditetapkan $(0,1)$.

$\mathrm{n}=\frac{N}{N(d)^{2}+1}$

$\mathrm{n}=\frac{13477}{13477(0,1)^{2}+1}$

$\mathrm{n}=\frac{13477}{13477(0.01)+1}$

$\mathrm{n}=\frac{13477}{135,77}$

$\mathrm{n}=$ Jadi jumlah sample adalah 92 responden

\section{PEMBAHASAN}

\subsection{Uji Asumsi Klasik}

\subsubsection{Uji Normalitas}

Uji normalitas dilakukan dengan uji Kolmogorov Smirnov dan diperoleh hasil pada tabel 1.

Tabel 1 .

Hasil Uji Normalitas

\begin{tabular}{lc}
\hline Nilai Sig & Unstandardized Residual \\
\hline Asymp. Sig. (2 - tailed) & .185 \\
\hline
\end{tabular}

Berdasarkan hasil analisis uji normalitas kolmogorov-smirnov diketahui bahwa nilai signifikansi yang diperoleh sebesar 0,185 lebih besar dari dari 0,5, sehingga dapat disimpulkan bahwa data yang diuji berdistribusi normal. 


\subsubsection{Uji Multikolinearitas}

Uji multikolinearitas dilakukan dengan Coefficients dan diperoleh hasil pada tabel 2.

Tabel 2.

Hasil Uji Multikolinearitas

\begin{tabular}{llcr}
\hline & \multicolumn{1}{c}{ Model } & $\begin{array}{c}\text { Collinearity Statistics } \\
\text { Tolerance }\end{array}$ & VIF \\
\hline 1 & (Constant) & & \\
& Persepsi Kemudahan &, 963 & 1,039 \\
& Kenyamanan &, 929 & 1,076 \\
& Kepercayaan &, 957 & 1,045 \\
\hline
\end{tabular}

Dari hasil pengujian di atas diketahui bahwa nilai Variance Inflation Factor (VIF) masing-masing variabel lebih kecil dari 10 (VIF $\leq 10$ ), nilai Tolerance lebih besar dari 0,10 (Tolerance $\geq 0,10$ ). Dari kedua hasil di atas, maka dapat disimpulkan bahwa antara variabel independen tidak terjadi persoalan Multikolinearitas.

$$
\mathrm{Uji} \mathrm{F}
$$

Tabel 3. Hasil Uji F

\begin{tabular}{rlrrrrr}
\hline \multicolumn{10}{c}{ ANOVA $^{\text {a }}$} \\
\hline \multirow{2}{*}{ Model } & Regression & Sum of Squares & df & Mean Square & F & Sig. \\
\hline \multirow{2}{*}{1} & Residual & 445,194 & 3 & 148,398 & 10,988 &, $000^{\text {b }}$ \\
& Total & 1188,458 & 88 & 13,505 & & \\
\hline
\end{tabular}

Berdasarkan hasil analisis diketahui bahwa $\mathrm{F}_{\text {tabel }}=\mathrm{F}(\mathrm{k} ; \mathrm{n}-\mathrm{k})=\mathrm{F}(3 ; 92-3)=\mathrm{F}(3$; 89), maka hasil $\mathrm{F}_{\text {tabel }}$ adalah 2,71. Adapun $\mathrm{F}_{\text {hitung }}$ sebesar 10,988. Maka hal tersebut dapat menunjukkan $\mathrm{F}_{\text {hitung }} 10,988>\mathrm{F}_{\text {tabel }} 2,71$. Hal tersebut membuktikan bahwa Ha diterima dan Ho ditolak. Sehingga dapat disimpulkan bahwa variabel independen (Persepsi kemudahan, kenyamanan, dan kepercayaan) secara bersama-sama atau simultan mempengaruhi variabel dependen (minat nasabah menggunakan mobile banking pada PT. Bank Aceh Syariah). 


\section{UJI T}

TABEL 4. Hasil Uji Signifikan Parsial (t test)

\begin{tabular}{llrrrrr}
\hline \multirow{2}{*}{ Model } & \multicolumn{2}{c}{$\begin{array}{c}\text { Unstandardized Coeffi- } \\
\text { cients }\end{array}$} & $\begin{array}{c}\text { Standard- } \\
\text { ized Coeffi- } \\
\text { cients }\end{array}$ & t & Sig. \\
\cline { 2 - 5 } & \multicolumn{2}{c}{ B } & Std. Error & Beta & & \\
\hline \multirow{2}{*}{1} & 21,453 & 5,072 & & 4,230 &, 000 \\
& $\begin{array}{l}\text { (Constant) } \\
\text { Persepsi kemu- } \\
\text { dahan }\end{array}$ &, 557 &, 203 &, 254 & 2,741 &, 007 \\
Kenyamanan &, 279 &, 197 &, 134 & 1,421 &, 159 \\
& Kepercayaan &, 938 &, 214 &, 407 & 4,384 &, 000 \\
\hline
\end{tabular}

Berdasarkan tabel di atas, maka dapat dilihat dan dijelaskan sebagai berikut:

1). Nilai $t_{\text {hitung }} X_{1}$ (Persepsi Kemudahan) sebesar 2,741. Hal ini berarti nilai $t_{\text {hitung }}>$ $\mathrm{t}_{\text {tabel }}(2,741>1,987)$, hasil perhitungan tersebut membuktikan bahwa $\mathrm{H}_{\mathrm{a}}$ diterima dan $\mathrm{H}_{\mathrm{o}}$ ditolak. Jadi dapat disimpulkan bahwa Persepsi kemudahan berpengaruh terhadap minat nasabah menggunakan mobile banking.

2). Nilai $t_{\text {hitung }} X_{2}$ (Kenyamanan) sebesar 1,421. Hal ini berarti nilai $t_{\text {hitung }<\text { tabel }}$ $(1,421<1,987)$, hasil perhitungan tersebut membuktikan bahwa $\mathrm{H}_{\mathrm{a}}$ ditolak da $\mathrm{H}_{\mathrm{o}}$ diterima. Jadi dapat disimpulkan bahwa kenyamanan tidak berpengaruh terhadap minat nasabah menggunakan mobile banking.

3). Nilai $t_{\text {hitung }} X_{3}$ (Kepercayaan) sebesar 4,384. Hal ini berarti nilai $t_{\text {hitung }} t_{\text {tabel }}$ $(4,384>1,987)$, hasil perhitungan tersebut membuktikan bahwa $\mathrm{H}_{\mathrm{a}}$ diterima dan $\mathrm{H}_{\mathrm{o}}$ ditolak. Jadi dapat disimpulkan bahwa faktor Kepercayaan berpengaruh terhadap minat nasabah menggunakan mobile banking.

\subsection{Faktor Yang Dominan Mempengaruhi Minat Nasabah Untuk Menggunakan Mobile Banking}

Dalam penelitian ini terdapat 3 faktor yang mempengaruhi mobile banking yaitu: faktor persepsi kemudahan, faktor kenyamanan dan faktor kepercayaan. Masing-masing faktor tersebut memiliki 4 item pernyataan yang terdapat dikuesioner, adapun pernyataannya disetiap masing-masing faktor adalah sebagai berikut:

1). Faktor persepsi kemudahan:

a. Sistem mobile banking mempermudah saya untuk menyelesaikan transaksi perbankan.

b. Mobile banking dapat menghemat waktu saya.

c. Mobile banking dapat diakses dimana saja, kapan saja selama tersedia jaringan internet. 
d. Mobile banking memberi banyak kemudahan dalam bertransaksi.

2). Faktor kenyamanan:

a. Sistem dalam mobile banking dapat dipahami dengan mudah.

b. Tidak terdapat antrian dalam bertransaksi menggunakan mobile banking.

c. Sistem dalam mobile banking sangat fleksibel untuk digunakan.

d. Saya merasa nyaman menggunakan mobile banking.

3). Faktor kepercayaan:

a. Mobile banking Bank Aceh Syariah dapat dipercaya.

b. Bank Aceh Syariah mampu melindungi data keuangan nasabah.

c. Saya percaya untuk menggunakan mobile banking karena Bank Aceh Syariah memiliki komitmen yang baik.

d. Bank Aceh Syariah memiliki kinerja memuaskan.

Berdasarkan hasil penelitian persamaan linier berganda bisa dilihat bahwa yang paling dominan adalah variabel Kepercayaan. Yaitu dengan hasil sebagai berikut:

1). Koefisien regresi variabel faktor persepsi kemudahan $\left(X_{1}\right)$ sebesar 0,557 atau $57,7 \%$.

2). Koefisien regresi variabel faktor kenyamanan $\left(X_{2}\right)$ sebesar 0,279 atau 27,9\%.

3). Koefisien regresi variabel faktor kepercayaan $\left(X_{3}\right)$ sebesar 0,938 atau 93,8\%.

Variabel yang paling berpengaruh diantara 3 variabel tersebut adalah variabel kepercayaan dengan hasil persamaan linier berganda sebesar 93,8\%.

Berdasarkan hasil Uji F dan Uji t juga dapat dilihat bahwa faktor yang paling dominan mempengaruhi minat nasabah menggunakan mobile banking adalah faktor Kepercayaan. Dengn hasil penelitian adalah sebagai berikut:

1). Nilai $t_{\text {hitung }} X_{1}$ (persepsi kemudahan) sebesar 2,741. Hal ini berarti nilai $t_{\text {hitung }}>t_{\text {tabel }}$ $(2,741>1,987)$.

2). Nilai $t_{\text {hitung }} X_{2}$ (kenyamanan) sebesar 1,421 . Hal ini berarti nilai $t_{\text {hitung }<\text { tabel }}$ $(1,421<1,987)$.

3). Nilai $t_{\text {hitung }} X_{3}$ (kepercayaan) sebesar 4,384 . Hal ini berarti nilai $t_{\text {hitung }}>t_{\text {tabel }}$ $(4,384>1,987)$.

Variabel yang paling tinggi nilai $\mathrm{t}_{\text {hitung }}$ nya adalah variabel kepercayaan dengan nilai 4,384 , jadi bisa kita ketahui variabel yang paling berpengaruh adalah variabel kepercayaan.

Berdasarkan data tersebut, maka pada penelitian ini membuktikan bahwa faktor atau variabel Kepercayaan merupakan faktor yang paling dominan mempengaruhi minat 
nasabah menggunkan mobile banking pada PT. Bank Aceh Syariah.

\section{KESIMPULAN}

Berdasarkan rumusan masalah pada penelitian ini maka hasil yang diperoleh adalah sebagai berikut:

1. Pada penelitian ini terdapat dua faktor yang mempengaruhi minat nasabah menggunakan mobile banking, yaitu: Faktor Persepsi Kemudahan dan Kepercayaan. Sededangkan faktor Kenyamanan tidak mempengaruhi secara simultan maupun parsial terhadap Minat Nasabah Menggunakan Mobile Banking. Hal tersebut dikarenakan:

- $\quad$ Nilai $t_{\text {hitung }} X_{1}$ (Persepsi Kemudahan) sebesar 2,741. Ini menunjukkan nilai $\mathrm{t}_{\text {hitung }}>\mathrm{t}_{\text {tabel }}(2,741>1,987)$, hasil perhitungan tersebut membuktikan bahwa $\mathrm{H}_{\mathrm{a}}$ diterima dan $\mathrm{H}_{\mathrm{o}}$ ditolak. Hal ini dapat disimpulkan bahwa Persepsi kemudahan berpengaruh terhadap minat nasabah menggunakan mobile banking.

- $\quad$ Nilai $\mathrm{t}_{\text {hitung }} \mathrm{X}_{2}$ (Kenyamanan) sebesar 1,421. Dinama hal ini berarti nilai $\mathrm{t}_{\text {hitung }}$ $t_{\text {tabel }}(1,421<1,987)$, hasil perhitungan tersebut membuktikan bahwa $\mathrm{H}_{\mathrm{a}}$ ditolak da $\mathrm{H}_{\mathrm{o}}$ diterima. Sehingga dapat disimpulkan bahwa kenyamanan tidak berpengaruh terhadap minat nasabah menggunakan mobile banking.

- Nilai $t_{\text {hitung }} X_{3}$ (Kepercayaan) sebesar 4,384. Hal ini berarti nilai $t_{\text {hitung }} t_{\text {tabel }}$ $(4,384>1,987)$, hasil perhitungan tersebut membuktikan bahwa $\mathrm{H}_{\mathrm{a}}$ diterima dan $\mathrm{H}_{\mathrm{o}}$ ditolak. Dapat disimpulkan bahwa faktor Kepercayaan berpengaruh terhadap minat nasabah menggunakan mobile banking.

2. Faktor yang paling dominan mempengaruhi minat nasabah menggunakan mobile banking adalah faktor kepercayaan. Hal tersebut dapat disimpulkan berdasarkan hasil uji regresi diperoleh hasil koefisien regresi variabel faktor persepsi kemudahan $\left(\mathrm{X}_{1}\right)$ sebesar 0,557 atau 57,7\%. Koefisien regresi variabel faktor kenyamanan $\left(\mathrm{X}_{2}\right)$ sebesar 0,279 atau $27,9 \%$ dan koefisien regresi variabel faktor kepercayaan $\left(\mathrm{X}_{3}\right)$ sebesar 0,938 atau 93,8\%.

Saran yang dapat penulis kemukakan sehubungan dengan hasil penelitian dan pembahasan yang dilakukan adalah:

1. Bagi PT Bank Aceh Syariah Cabang Lhokseumawe Capem Keude Krueng Geukueh perlu memberikan sosialisi kepada nasabah tentang keuntungan yang akan didapat jika menggunakan mobile banking, agar nasabah tetap mau menggunakan mobile banking dimasa yang akan datang. Bank juga lebih meningkatkan tingkat keamanan dan menjaga privasi nasabah. Untuk meper- 
tahankan bahkan lebih meningkatkan variabel kepercayaan yang merupakan variabel yang dominan mempengaruhi minat nasabah menggunakan mobile banking.

2. Untuk agenda penelitian kedepan peneliti menyarankan menganalisiskan beberapa variabel bebas. Penelitian ini hanya menggunakan tiga variabel bebas, sehingga bagi peneliti yang selanjutnya bisa menambahkan variabel bebas lainnya seperti: kredibilitas, manfaat, daya guna, resiko dan kualitas layanan

\section{PUSTAKA}

Alma, Buchari, Manajemen Bisnis Syariah: Sebuah Kajian Historis dan Kontemporer. 2006. Jakarta: Raja GrafindoPersada,.

Alma, Buchari. Manajemen Pemasaran dan Pemasaran Jasa. 2016.Bandung: Alfabeta,.

Arif, M. Nur Rianto Al. Lembaga Keuangan Syariah: Suatu Kajian Teoritis Praktis. 2012. Bandung: Pustaka Setia.

Arikunto, Suharsimi. Manajemen Penelitian. 2005. Jakarta: Rineka Cipta,.

Bungin, Burhan Metode Penelitian Kuantitatif, 2005. Jakarta: Kencana Prenada Media Group,.

Febrian Maulana Yusuf, Faktor-Faktor yang Mempengaruhi Minat Menggunakan Internet Banking Pada Nasabah BRI Syariah Yogyakarta, digilib.uin-suka. ac.id,

Fadhil, Muhammad dan Rudy Fachruddin, Pengaruh Persepsi Nasabah Atas Risiko, Kepercayaan, Manfaat, Dan Kemudahan Penggunakan Terhadap Penggunaan Internet Banking2016, Jurnal Ilmiah Mahasiswa Ekonomi Akuntasi (JIMEKA), Vol. 1, No. 2,

Faramita Dwitama, faktor-faktor yang mempengaruhi minat nasabah menggunakan internet banking dengan menggunakan tecnology Acceptance Model (TAM) pada bank Mandiri, http://ejournal.gunadarma.ac.id,

Gazoli, Iman, Aplikasi Analisa Multivariade dengan Program SPSS, edisi I. 2011, Semarang: Universitas Diponogoro.

Kotler, Philip \& Gary Amstrong, Prinsip-Prinsip Pemasaran. Edisi 12 jilid 1. 2008 Jakarta: Erlangga.

Kotler, Philip \& Kevin Lane Keller. Manajemen Pemasaran. Edisi 13 Jilid 1. 2008. Jakarta: Erlangga,

Kasmir, Pemasaran Bank, Edisi Revisi. 2008. Jakarta: Kencana,

Mahmud, Amir dan Rukmana, Bank Syariah Teori, Kebijakan dan Studi Empiris di Indonesia, Jakarta: Erlangga, 2010. 
Ridwan, Belajar Mudah Penelitian Untuk Guru, Karyawan, dan Peneliti Pemula, 2007. Bandung: Alfabeta.

Shalahuddin, M. Lembaga Ekonomi dan Keuangan Islam., 2006. Jakarta: Ums Press.

Slamento, Belajar dan faktor-faktor yang mempengaruhi. 2007. Jakarta: Rineka Cipta.

Supriyono, Maryanto, Buku Pintar Perbankan. 2010. Yogyakarta: Andi.

Siregar, Syofian, Metode Penelitian Kuantitatif: Dilengkapi perbandingan perhitungan manual \& SPSS, Jakarta: Kencana Prenada Media Group, 2013.

Sugiyono, Metode Penelitian Kuantitatif Kualitatif dan R\&D. 2011.Bandung: Alfabeta.

Triwerthy, Komang, Manajemen Pemasaran. 2012. Lampung: LPPM STIE Lampung,

Umam, Khotibul, Perbankan Syariah: Dasar-dasar dan Dinamika Perkembangannya, 2016. Jakarta: RajaGrafindo Persada.

Anggraeni, Rila, Pengaruh Persepsi Kemudahan Penggunaan dan Persepsi Kegunaan Terhadap Niat Untuk Menggunakan dan Penggunaan Aktual Layanan Jejaring Sosial Berbasis Lokasi(Studi pada Mahasiswa Fakultas Ekonomi dan Bisnis Universitas Brawijaya Malang), https://media.neliti.com.

Dwitama, Faramita, faktor-faktor yang mempengaruhi minat nasabah menggunakan internet banking dengan menggunakan tecnology Acceptance Model (TAM) pada bank Mandiri, http://ejournal.gunadarma.ac.id

Fadhil, Muhammad dan Rudy Fachruddin, Pengaruh Persepsi Nasabah Atas Risiko, Kepercayaan, Manfaat, Dan Kemudahan Penggunakan Terhadap Penggunaan Internet Banking, Jurnal Ilmiah Mahasiswa Ekonomi Akuntasi (JIMEKA). 2016. Vol. 1, No. 2,

Nisa, Dede Dzurotun, Tyas Silvi Ariyani dan Karina Oktaviani, Analisis Faktor-Faktor Yang Mempengaruhi Nasabah Menggunakan Layanan Internet Banking Mandiri, Jurnal Manajemen, 2013.Vol.13, No.1, November 